\title{
Necessidade de Atualização da Reparação pelo dano à Pessoa Humana*
}

\author{
Antônio Chaves \\ Diretor da Faculdade de Direito e Catedrátics de \\ Direito Civil na Universidade de São Paulo
}

\begin{abstract}
SUMÁRIO: 1. Responsabilidade penal e responsabilidade civil (aquiliana). 2. O rol dos atos lesivos. Comecemos pelo homicídio. 3. Dano à integridade psíquica. 4. Ferimento ou outra ofensa à saúde. 5. Dano estético à mulher casadoira. 6. Defeito que impeça o exercicio de ofício ou profissão. 7. Crime justificável. 8. Responsabilidade civil dos que participam de produtos de um crime. 9 . É necessário disciplinar o egoismo humano.
\end{abstract}

\section{Responsabilidade penal e responsabilidade civil (aquiliana)}

Varia muito a reação social, na conformidade da repercussão produzida pelo ato lesivo. Natural, portanto, a separação entre a responsabilidade penal e a civil, também averiguadas de modo diferente: enquanto aquela é apurada com maior rigor, escapando à sua disciplina a culpa levíssima, no direito civil o mínimo proceder culposo dá margem à reparação.

Não são idênticos os princípios, nem coincidentes os ilícitos. Tanto assim que só há crime quando o ato é como tal catalogado pela lei, ao passo que para que seja considerado ilícito civil, não é preciso seja criminoso.

Atente-se ainda a que, mesmo que não criminoso, o fato pode produzir responsabilidade civil.

Por isso mesmo ressalva o art. 1.525 do Código Civil pátrio, depois de separar ambas as responsabilidades, não se poder questionar mais sobre a existência do fato, ou quem seja o seu

* Aula proferida no dia 22.08.1980, inaugurando o Curso de Estudo de Problemas Brasileiros, nos Cursos de Pós-Graduação da Faculdade de Direito da U.S.P. 
autor, quando tais questões já estiverem decididas no crime, proclamando, assim, a independência entre ambas as esferas de responsabilidade.

Tem-se salientado reunir a responsabilidade penal ao caráter repressivo, o preventivo, predominando o interesse coletivo, que é o da defesa da sociedade organizada, ao passo que a responsabilidade civil visa antes o interesse individual, para devolver ao prejudicado, pela reparação, tanto quanto possível, a situação em que se encontrava anteriormente ao ato, fato ou omissão lesivos, proporcionando-lhe uma importância em dinheiro que corresponda o mais possível ao valor do prejuízo sofrido.

"A ação de responsabilidade civil" - observa Rafael Duran Trujillo, Nociones de Responsabilidad Civil (Contractual y Delictuosa), Bogotá, Temis, 1957

- "não escapa nenhuma infração penal por grave ou pequena que seja, desde o homicídio intencional até o caso mais leve de polícia. O Código Civil não excetua nenhum fato ilícito da pena de indenização, que, pelo contrário, compreende todo ato punível que lese o patrimônio material e moral de uma pessoa. Por isso desempenha na responsabilidade civil papel tão relevante a imprudência, a negligência e o descuido das pessoas e dos funcionários privados e públicos, como também o fato intencional ou doloso destas mesmas pessoas.

"É esta a razão pela qual, para que exista responsabilidade civil delitual e contravencional basta que se haja produzido qualquer gênero de infração contra a lei penal.

"Nesta matéria, a fonte é o ato ilícito, que dá lugar a uma ação chamada de responsabilidade, quando sobrevém um fato intencional, negligente ou puramente contravencional da pessoa, razão por que aos nossos olhos aparece com facilidade o seguinte esquema: fonte, o delito e a contravenção; obrigação, a de indenizar o prejuízo ou dano; fato, o homicídio, o roubo, o atentado contra a honra, etc."

Encarece, todavia, que a responsabilidade penal e a responsabilidade civil por crimes e contravenções, implicam em conceitos opostos. Não têm o menor limite de contato, com exceção do fato que as origina.

Uma impõe como sanção uma pena, que pode ser reclusão, detenção ou multa (penas principais) ou perda de função pública, interdições de direitos e publicação da sentença (acessórias) ; a outra aplica como castigo uma indenização natural ou em dinheiro. 
Aponta as diferenças existentes entre a pena e a indenização: com aquela sanciona-se o crime e a contravenção; com esta repara-se o dano material, incorporal e moral de afeição. A pena determina-se pela culpabilidade do agente, ou por sua maior ou menor periculosidade, segundo FERRI; a indenização mede-se pelo prejuízo ocasionado à vítima.

"A pena subsiste mesmo que o fato não cause lesão à pessoa, como na tentativa de crime, que é sempre castigada; a indenização nunca se produz sem que intervenha um prejuízo. A pena tem uma finalidade econômica quando é multa, mas então diferencia-se da indenização em dinheiro, em que aquela se extingue ao desaparecer o fato delituoso, e a indenização permanece incólume até que se cancele, salvo os casos de prescrição; também porque a multa, não sendo paga a seu devido tempo converte-se em prisão, e a indenização não sofre qualquer transformação natural, quando é em dinheiro."

E delicado o mecanismo da entrosagem entre a responsabilidade penal e a civil.

Determinadas circunstâncias existem que excluem a primeira sem que, por isso, fique eliminada.

Mesmo quando aquela não seja reconhecida, pode a lei fazer decorrer esta não só de quem cometeu o fato, mas de outrem que se encontre sob a sua guarda e responsabilidade (responsabilidade indireta).

Uma coisa, porém, é certa: reconhecido um ato criminoso no juízo penal, não cabe mais qualquer discussão sobre o seu caráter ilícito.

Separadas como estão as jurisdições, exige uma questão de coerência que haja alguma harmonia entre ambas.

São dois os critérios existentes: o da interdependência e o da independência.

O primeiro fora seguido pelo Código Criminal do Império, não admitindo o art. 31 tivesse lugar a satisfação do dano antes da condenação do delinqüente por sentença do juízo criminal, passada em julgado, apontando algumas exceções.

o Código de Processo Criminal de 1832 incluia, entre as questões propostas aos jurados indagação "se há lugar à indenização". 
Caso não tivesse o delinqüiente meios para satisfação, dentro em 8 dias que lhe seriam assinados - dispunha o art. 32 daquele - seria condenado à prisão com trabalho, pelo tempo necessário para ganhar a quantia da satisfação, ficando sem efeito essa condenação tão logo o criminoso, ou alguém por ele, satisfizesse o débito, ou prestasse fiança idônea, ou o ofendido se desse por satisfeito.

$\mathrm{O}$ art. 31 do Código Criminal foi no entanto revogado pela Lei n. 261 de 3-12-1841, dispondo que a indenização, em todos os casos, seria pedida por ação civil, aditando que não se poderia, porém, questionar mais sobre a existência do fato ou quem seja o seu autor, quando estas questões se achassem decididas no crime, norma que passou para o art. 1.525 do Código Civil, e que é complementada pelo Código de Processo Penal, arts. 63 a 67.

Por reparação ou indenização entende-se a colocação à disposição da vítima do próprio bem do qual foi espoliada, ou o prejuízo sofrido, ou, quando não seja possível, os valores em dinheiro ou em outros bens que a façam sentir-se a mais próxima possível da situação anterior ao fato.

Independente como passou a ser hoje a ação civil de indenização da ação criminal, poderá ser intentada antes, simultaneamente ou depois.

Revelando, todavia, a influência que tem a sentença condenatória criminal sobre o resultado da ação civil, faculta 0 art. 63 do Código de Processo Penal, transitada em julgado a sentença condenatória, que o ofendido, seu representante legal, ou seus herdeiros promovam-lhe a execução no juízo cível, para o efeito da reparação do dano.

Passada pois em julgado a respectiva sentença, não se admite mais discussão sobre a existência do crime e sobre sua autoria, como resulta do art. 1525 do Código Civil, podendo a sentença penal condenatória ser executada no âmbito civil.

De que modo?

Pela ação civil de indenização, que se limitará à verificação da existência do dano e à apuração do respectivo montante.

Só o autor do crime, ou seus herdeiros diretos, responderão pela execução.

Mas a sentença condenatória penal pode alcançar responsáveis indiretos, muito embora não se deva falar, com propriedade, nesse caso, em execução da sentença criminal. 
Assim, condenado o empregado ou preposto, não terá o patrão, na ação que lhe for movida, condições de por em dúvida a existência do ato, nem a autoria do mesmo, poupando-se, por essa forma, tempo e trabalho ao ofendido.

0 art. 64 do Código de Processo Penal deixa claro que a ação civil de indenização pode ser proposta antes de iniciada a ação penal, ou no decorrer da mesma, admitindo no entanto o parágrafo único suspenda o juiz, perante quem corre a ação civil, o seu curso, até o julgamento definitivo da ação penal.

Objetiva-se, com isso, evitar decisões conflitantes.

As expressões usadas pelo dispositivo não deixam margem às dúvidas que antes ocorriam sobre a circunstância de que uma decisão cível seja ainda passível de alteração. É preciso que tenha transitado em julgado na superior instância, sem que haja possibilidade de rescisão do julgado, para que se possa considerar definitiva.

Sem embargo de todas essas cautelas, podem ocorrer decisões conflitantes nas duas esferas. Assim, condenado o réu no juízo cível a reparar o dano, têm-se registrado eventualidades de que, no juízo penal, acabe sendo absolvido pela negativa de ter sido ele o autor do crime.

$\mathrm{Ou}$, vice-versa, que ele, proclamado na ação civil não ser o autor do fato que lhe é atribuído, receba em seguida condenação na justiça penal.

Não sendo mais cabível ação rescisória da sentença final, ou sendo esta julgada improcedente, manifesta-se a contradição.

0 reconhecimento de ter sido o ato praticado em estado de necessidade, legítima defesa, ou no exercício regular de um direito ou em estrito cumprimento de um dever legal (art. 65 do Código de Processo Penal), em sentença absolutória penal, prevalece no âmbito civil, sem que se possa dizer com propriedade ocorrer coisa julgada, na expressão desse dispositivo, mas de eficácia da sentença criminal em relação à ação civil.

Proclamado o ato como lícito pela justiça criminal, firma-se o princípio da inadmissibilidade de servir de fundamento na ação civil, sem que, não obstante, impeça a propositura da ação civil de reparação, pois aí temos um daqueles casos de responsabilidade civil pelo dano causado independentemente do caráter ilícito do ato. Os arts. 1519 e 1520 do Código Civil não foram revogados pelo art. 65 do Código de Processo Penal.

A sentença absolutória criminal chega mesmo a estabelecer uma presunção de responsabilidade civil do acusado, uma 
vez que não se poderá mais discutir no âmbito cível, a existência do fato ou sua autoria. Somente se conseguir provar ter sido o dono da coisa danificada ou deteriorada o culpado do perigo, é que o autor do fato poderá destruir a presunção que pesa contra ele.

O despacho de arquivamento do inquérito ou das peças de informação (art. 67 do Código de Processo Penal) fundamentado na falta de prova suficiente, nada decide sobre a existência do fato nem sobre sua autoria. Mesmo porque, enquanto não extinta, a ação ainda poderá ser intentada.

$\mathrm{O}$ mesmo se dirá com relação à morte do acusado, sua anistia ou indulto, da aplicação de lei penal mais benigna, da prescrição da ação penal, ou da condenação, da perempção, da retratação do acusado, do perdão do ofendido, da renúncia do direito de queixa, etc. (art. 67 citado).

Mesmo a sentença absolutória que decidir que o fato imputado não constitui crime não implica no reconhecimento de que não possa ser um ilícito civil. Assim o réu, acusado do crime de defloramento de menor de 18 e maior de 14 anos, apenado com reclusão de dois a seis meses (art. 215 do Código Penal), absolvido por não resultar provado o requisito da sedução, poderá, isso não obstante, ser obrigado à reparação do dano.

Finalmente, a absolvição do réu por falta de imputabilidade penal não implica nos mesmos efeitos com relação à responsabilidade civil, justamente por serem independentes ambas as esferas.

\section{O rol dos atos lesivos. Comecemos pelo homicídio}

As disposições do CC agrupam-se em torno de nove assuntos principais:

a) homicídio, art. 1537;

b) ofensa à saúde, art. 1538 ;

c) usurpação ou esbulho, arts. 1542 e 1543 ;

d) danos causados por médicos, cirurgiões, farmacêuticos, parteiras e dentistas, arts. 1545 e 1546;

e) injúria ou calúnia, art. 1547;

f) agravo em honra de mulher, art. 1548;

g) demais crimes de violência sexual, ou ultraje ao pudor, 1549 ; 
h) ofensa à liberdade pessoal, 1550-1552;

i) hipóteses não previstas, art. 1553.

A esses casos a legislação subseqüente veio acrescentando numerosos outros:

j) penas indenizatórias de caráter pecuniário enumeradas não só em grande número de artigos do Código Penal, como ainda, em abundantíssimas leis complementares;

1) indenizações decorrentes de acidentes de trabalho; tes;

m) indenizações decorrentes de acidentes nos transpor-

n) violações de direitos de autor, art. 122 da Lei n. 5988, de 14-12-1973;

o) violações aos direitos dos artistas de gravação e reprodução de interpretações, art. $9 .^{\circ}, \S 3 .^{\circ}$ da Lei n. 4.944 , de 06-04-1966;

p) danos causados em pesquisas de minérios, Decreto n. 227, de 28-02-1967, Código de Mineração, art. 27, etc.

Percorramos então, várias hipóteses, analisando as soluções, infelizmente, completamente falhas do legislador.

O homicídio é a primeira e a mais grave das hipóteses, à qual o Código Penal comina a pena-base de reclusão de 6 a 20 anos, catalogando ainda o induzimento, instigação ou auxílio ao suícidio, o infanticídio e o aborto.

Enquanto que esse estatuto, por sua natureza, tem que fazer uma enumeração a mais completa e sistemática possível de todos os crimes, tratando-os pela importância decrescente, - o Código Civil, regulando a liquidação das obrigações decorrentes dos atos ilícitos nos arts. 1537-1553, não seguiu qualquer método, elaborando uma lista que hoje resulta anacrônica, assistemática e incompleta, cuidando sucessivamente de homicídio, atentado à integridade física, crime justificável, usurpação ou esbulho, responsabilidade dos médicos, cirurgiões, farmacêticos, parteiras e dentistas, crimes contra a honra, a boa fama, violência sexual, contra a liberdade pessoal e demandante improbo.

Flagrante o retrocesso, em comparação aos preceitos legais anteriores, compendiados na Consolidação de TEIXEIRA DE FREITAS, que em preceitos genéricos, limitava-se, invocando o art. 22 do Código Criminal a dispor:

"Art. 800 - A indenização será sempre a mais completa, que for possível: em caso de dúvida, será a favor do ofendido. 


\section{“Art. 801 - 0 mal será avaliado em todas as suas conseqüências."}

CLOVIS BEVILÁQUA não aceitou o critério, por entender que atribuiria ao juiz arbítrio.

Deixou manifesta uma excessiva preocupação em que não sirva a reparação de pretexto para um enriquecimento ilícito mediante exploração por parte da vítima. Caberia ao réu defender-se, impugnando as verbas que considerasse exageradas, e exigindo um arbitramento razoável.

Por isso considerando a morte sob ponto de vista diferente, sem implicações criminais: desde que tenha ocorrido por ato ou omissão que possa ser imputado a uma pessoa, mesmo sem culpa de sua parte, imediatamente, ou após longo período, a indenização, concedida pelo CC, nos termos do art. 1537, consistirá:

"I - No pagamento das despesas com o tratamento da vítima, seu funeral e o luto da família;

II - Na prestação de alimentos às pessoas a quem o defunto os devia."

Mas o que é certo é que, por essa forma, não concede o Código uma indenização, mas apenas um paliativo, excessivamente moderado, que fica mil milhas distantes do verdadeiro objetivo.

Dia a dia torna-se mais patente que os limites por ele fixados estão em completa desarmonia com uma política eficiente de desestímulo aos atos delituosos ou meramente culposos.

Quanto vale, na verdade, uma vida humana?

A questão tem sido posta dramaticamente pelos resgates de milhões exigidos pelos seqüestradores para devolver a liberdade de pessoas importantes. E, na verdade, não há fortuna que a pague.

Não tão dramáticos, mas igualmente expressivos, os mirabolantes passes pagos pelos nossos melhores futebolistas: Falcão "vendido" pelo Internacional de Porto Alegre ao Roma, em julho deste ano, por 4,3 milhões de dólares, na ocasião cerca de Cr $\$ 233$ milhões; Enéas, pela Portuguesa, ao Bolonha, por $\mathrm{Cr} \$ 50$ milhões; Sócrates pregando um susto em Matheus, ao pretender 20 milhões de cruzeiros de luvas além de $400 \mathrm{mil}$ de salários.

No boxe, Sugar Ray Leonard teve uma bolsa de US\$ 8 milhões, quando tentou defender o título mundial dos meio-mé- 
dios contra Roberto Mano de Piedra Duran, que por sua vez, obteve US $\$ 2$ milhões, no dia 20 de junho último.

Mas o maior contrato da história do esporte mundial continua sendo o assinado no dia 10-06-1975 por Pelé e pela Warner Communications: 72 milhões.

Cr\$166.000,00 por segundo que jogasse futebol, sem contar os royalties advindos da marca com o seu nome, em quantia muito maior, e os contratos de relações públicas.

Ficamos pasmos, por isso, ao verificar a parcimônia, a verdadeira miserabilidade com que esta matéria foi tratada pelo Código Civil.

São incalculáveis os prejuízos decorrentes da desastrosa influência que o critério veio a exercer sobre a nossa doutrina, e reflexamente, sobre a jurisprudência, ainda hoje demasiadamente aferrada a textos de leis mais do que antiquados, arcaicos, rançosos, antes preocupados com o criminoso do que com a vítima.

Bem se percebe a diferença das conseqüências entre a morte, que elimina de qualquer consideração a própria vítima, para fixar a atenção no cônjuge e parentes mais próximos, que sofrem dano irreparável, aos quais passará, nestas condições, a titularidade para reclamar a reparação do dano, e todos os demais casos, que atingem a própria pessoa do ofendido.

Quando a morte não é imediata, obriga o agente ao pagamento de todas as despesas com o tratamento. Não apenas a assistência médica e hospitalar, medicamentos, etc., como os recursos utilizados no esforço de salvar-lhe a vida, que podem ser ingentes, no caso de localização de desaparecidos ou de seqüestro, despesas para procura em lugares diferentes, anúncios, promessas de recompensa e até mesmo resgates.

Tem-se apontado a contradição flagrante entre o aludido art. 1.537 e o do art. 1.538 que, para o caso de ferimento prevê, além das despesas de tratamento, lucros cessantes até o fim da convalescença, o pagamento da multa no grau médio da pena criminal correspondente, soma a ser duplicada se do ferimento resultar aleijão ou deformidade, etc.

Nessa delicadíssima matéria da indenização por morte, já de per si, tão dolorosa, é lastimável a situação dos pais que perdem um filho, muitas vezes seu único arrimo.

E mais amargurada ainda, quando se trata de filho menor.

A jurisprudência tem sido excessivamente distanciada da realidade, ao só admitir indenização quando o filho contribua 
para a economia doméstica. Pois, ainda que seja menor, tolhida que lhe foi a vida, considerando a matéria em seu aspecto menos relevante, o material, não fica eliminada a certeza de que, atingida a puberdade, poderia contribuir para o sustento da família.

Invocando como referência os arts. 1.537, II e $1.533 \mathrm{CC}$, 911 e 912 CPC, RE 53.404, 03-5-1967, Pleno (RTJ 42/378); RE 65.281, de 23-9-1968, 1. ${ }^{\text {a }}$ T. (RTJ 47/279) e RE 59.940, 14-6-1966, 2. ${ }^{\text {a }}$ T. (RTJ 39/38), estabeleceu o Supremo Tribunal Federal o princípio de que:

"É indenizável o acidente que cause a morte de filho menor, ainda que não exerça trabalho remunerado."

Sem embargo dessa clara demonstração de clarividência e compreensão, persistem os tribunais em recorrer a evasivas, que tanto favorecem os criminosos e os irresponsáveis, como agravam a situação das vítimas:

"Fugindo-se ao rigor do disposto no art. 1.537, n. II, do CC, bem assim ao extremo liberalismo da Súmula n. 491 do STF, de se firmar que, em caso de morte de menor, por ato ilícito, a indenização só será devida quando ele, de qualquer forma, contribuía à economia doméstica."

TJSP - Câms. Civ. Reuns. - rev. n. 199.065 Santos - j. 10-5-1974 - maioria de votos.

As despesas de funeral abrangem enterro, sepultura, sufrágios, evitando-se, porém abusos. Compendiando o sentimento da doutrina, recomenda CARVALHo SANTOS fiquem adstritas às condições sociais do morto. Não se justifica um enterro pomposo para vítima que sempre viveu modestamente, e cujos recursos seriam incompatíveis com exageros. Cada caso, nas suas circunstâncias, é que deverá orientar o juiz.

Também as despesas do luto da família terão que pautar-se com a condição social da mesma.

Mas é o item alimentos, que realça logo em importância. O maior prejuízo material sofrido pelos familiares do morto decorre da privação do auxílio e concurso, que dele recebiam, para sustento de todos e educação dos filhos.

Não encontrou o legislador critério melhor para a indenização do que a prestação de alimentos, como substitutivo das perdas e danos, sem que, todavia, fique dispensada a obrigação de indenizar por outra forma o dano causado por pessoa de amplos cabedais pela morte. 
Será o suficiente para que se verifique que a palavra alimentos não é aqui tomada no mesmo sentido que tem no tocante à prestação devida entre parentes, no direito de família, principalmente arts. 396-405: a analogia não passa de um parâmetro destinado a indicar o limite da indenização.

A diferença entre ambas as espécies ressalta, em primeiro lugar, da invariabilidade do montante no caso da indenização, ao passo que, naquele caso, pode ser aumentada, ou mesmo reduzida.

Em segundo lugar, entre parentes, são fixados, art. 400, na proporção das necessidades do reclamante e dos recursos da pessoa obrigada, ao passo que, no caso de indenização, ainda que a fortuna da vítima seja maior do que a do autor do dano, não poderá este furtar-se ao cumprimento da obrigação.

Também não altera a situação o fato da vítima ganhar na loteria, ser beneficiado de um seguro, ou de vantagens previdenciárias.

Bem diferente a solução em direito da família: fixados os alimentos, alí, a sobrevinda de mudança de fortuna de quem os recebe, autoriza o art. $401 \mathrm{CC}$ o interessado reclamar do juiz, conforme as circunstâncias, exoneração, redução ou agravação do encargo.

Ainda: só os parentes podem exigir, uns dos outros, os alimentos, de que necessitem para subsistir (art. 396), ao passo que, na responsabilidade civil, essa circunstância não entra em consideração.

A companheira, assim como o filho de criação, que da vítima recebiam sustento, terão direito à indenização.

Como a obrigação de indenizar encontre nos alimentos apenas a expressão de sua "prestação", somente para fins de cálculo e de liquidação sob a forma de pensão, a indenização será devida, mesmo nas hipóteses em que o falecido não estava em condições de prestar alimentos. $O$ fato de serem escassos ou precários os meios de subsistência da vítima, poderá ser levado em conta no cálculo da indenização, mas não para que esta não seja concedida. A vida representa sempre um valor econômico, reconhecido até mesmo nas eventualidades em que a vítima não tivesse obrigação legal de prestar alimentos.

\section{Dano à integridade psíquica}

Se o maior patrimônio do homem é ele próprio, há que considerar qualquer lesão que o possa atingir em seus duplos 
atributos, psíquicos, espirituais, intelectuais e materiais, físicos ou corporais.

A matéria interessa não só ao indivíduo, como à Nação, à própria humanidade. Quanto melhor se puder preservar o patrimônio intelectual de cada qual, possibilitando-lhe retirar de sua personalidade as imensas riquezas inexploradas que aí jazem, tanto mais rica, próspera e feliz será a inteira coletividade.

Por antigo vezo costuma-se analisar a matéria pelas lesões de que possa ser vítima o indivíduo no seu físico, quando o mais importante seria ressaltar os graves prejuízos que pode sofrer o seu espírito, levando-o, por circunstâncias várias, a estado de desequilíbrio, ou mesmo de insanidade mental.

Numa época como a nossa, em que seqüestradores detêm reféns durante meses a fio, submetendo-os a vexames, humilhações, maus tratos que podem levá-los à instabilidade e à loucura, em que regimes totalitários erigem em perigo para a segurança coletiva a mínima dissenção, qualquer profissão de fé que não esteja na mais completa consonância com a orientação dominante e reprimindo violentamente contestações, submetendo a "hospitalização" e "tratamento psiquiátrico" por meio de drogas e choques os dissidentes, - bem se percebe como é frágil e sem defesa a preservação desse dom, que vem logo após a própria vida: a integridade psíquica.

De que vale a vida sem discernimento?

Caso bem expressivo é o ocorrido em 1978 de um jovem, para salvar cuja vida a família pagou milhões de liras, sob a promessa de que seria devolvido vivo. O corpo foi, efetivamente, entregue com vida, mas castrado, cego e completamente abúlico.

A morte não teria sido mais piedosa?

Provada a relação de causalidade, não há como não fazer com que os responsáveis, quando possível, reparem o mal causado.

Sustenta Pietro Perlingieri, La Personalitá Umana nell' Ordinamento Giuridico, Camerino, Jovene, 1972, pág. 231, que a proteção da integridade psíquica atua-se também nos casos em que a norma ordinária limita-se a proteger a integridade física.

Nestas condições, tanto a alusão contida no art. 1.538 do Código Civil ao ferimento, e, principalmente, a "outra ofensa à saúde", como a do art. 129 do Código Penal, quando se refere à ofensa à integridade corporal ou à saúde de outrem, abrangem, também, a integridade da saúde psíquica. 


\section{Ferimento ou outra ofensa à saúde}

No caso de ferimentos ou ofensas físicas, algumas distinções precisam ser estabelecidas. Ensaia-as o CC pátrio estabelecendo quatro hipóteses diferentes.

A primeira é de ferimento ou outra ofensa à saúde: despesas de tratamento, lucros cessantes até o fim da convalescença, pagamento de importância correspondente à multa no grau médio da pena criminal correspondente (art. 1.538, caput).

Estarão incluídas, na indenização, todas e quaisquer despesas inerentes ao tratamento: hospitalização, intervenções cirúrgicas, assistência médica, medicamentos, aparelhos ortopédicos etc., a serem devidamente comprovadas, reconhecido ao juiz um certo arbítrio para cobrir exageros.

Os lucros cessantes até o fim da convalescença, são os indispensáveis, desde o início até o término do tratamento, e o restabelecimento da saúde, mesmo que permaneça algum defeito ou incapacidade.

Caso o ofendido, em conseqüência da ofensa física, que recebeu, seja afastado de sua atividade, ficando privado da correspondente remuneração, terá que receber a indispensável compensação, a ser devidamente sopesada pelo juiz.

Tais lucros cessantes não podem ir além do que o ofendido deixou de ganhar com o afastamento temporário da sua atividade normal. Um menor impúbere, ou uma pessoa que não exercia qualquer atividade remunerada, nada poderá reclamar a título de lucros cessantes, assim como quem, não obstante a inatividade, não tenha ficado privado dos seus ganhos normais.

A verba da indenização é paga por pessoa que não a causadora da ofensa, nos casos indicados no art. 1.521 CC:

I - Os pais, pelos filhos menores que estiverem sob seu poder e em sua companhia.

II - O tutor e o curador, pelos pupilos e curatelados, que se acharem nas mesmas condições.

III - O patrão, amo ou comitente, por seus empregados serviçais e prepostos, no exercício do trabalho que lhes competir, ou por ocasião dele (art. 1.522).

IV - Os donos de hotéis, hospedarias, casas ou estabelecimentos, onde se albergue por dinheiro, mesmo para fins de educação, pelos seus hóspedes, moradores e educadores.

$\mathrm{V}$ - Os que gratuitamente houverem participado nos produtos do crime, até à concorrente quantia. 
A segunda hipótese é a de ferimento de que resulte aleijão ou deformidade: a soma será duplicada (§ $\left.10^{\circ}\right)$.

Pelo mesmo crivo de insuportável mediocridade passa a multa a que se refere o caput do art. 1.538, só cabível no caso de resultar a ofensa de crime de lesão corporal dolosa, única eventualidade em que aplica a alternativa de multa do art. 129, $\S 5 .^{\circ}$ do Código Penal. Sendo, hoje (1980) de Cr\$ 400 a $\mathrm{Cr} \$$ 4.000, a média será de Cr\$2.220.

Será que tais pagamentos mesmo em dobro, quando efetivados, satisfarão as dezenas de milhares de aleijados, vítimas das máquinas modernas?

Mas o pior é que, mesmo quando ocorra essa eventualidade, ainda resiste a jurisprudência em conceder indenizações, mais do que devidas.

Assim, decidiu, aos 18-5-1950, o Tribunal de Justiça de São Paulo, Rev. dos Tribunais, vol. 188/184:

"O elemento principal na conceituação do aleijão ou deformidade, para aplicação do art. 1.538, § $1 .^{\circ}$, do Código Civil, é a aparência.

Se o aleijão ou deformidade não ocasionar má aparência, ou não for de molde a causar impressão desagradável de seu portador, nem exercer qualquer influência na sua atividade profissional, não é possível admiťrir-se o cabimento da duplicação a que alude o dispositivo, porque não haverá qualquer dano moral, ou material, que pudesse justificá-la. A ósteo-artrite como causa da limitação de movimentos da perna, não deve ser levada em linha de conta para a classificação da redução da capacidade do indivíduo vitimado. Pouco importa que a redução seja conseqüência de uma ou de várias causas. Sempre será uma única a incapacidade."

\section{Dano estético à mulher casadoira}

Terceira hipótese: se o ofendido, que ficou aleijado ou deformado, for mulher solteira ou viúva, ainda capaz de casar, a indenização do dano estético já não consistirá na duplicação das despesas de tratamento e dos lucros cessantes, mas "em dotá-la, segundo as posses do ofensor, as circunstâncias da ofendida e a gravidade do defeito" ( $\left(2 .^{\circ}\right)$. 
Considera a lei apenas o dano estético sofrido por mulher ainda capaz de casar, que perca a oportunidade de fazê-lo, limitando pois a reparação às categorias de mulher solteira, ou viúva, que tenha sofrido aleijão ou deformidade.

Fica excluída a mulher que, por alguma circunstância personalíssima, como a insanidade mental, não tenha capacidade nupcial.

Nem idade avançada, nem a fealdade, tornam a mulher incapaz de casar, mesmo porque, como observa AGUIAR DiAs, sob esse aspecto, a capacidade de casar dependeria do ânimo de quem a queira para esposa.

A circunstância da idade e outros dados personalíssimos, que possam influir na possibilidade do casamento, serão levados em conta no cálculo do dote, sem excluir, porém, a indenização.

Semelhante constituição de dote tem caráter definitivo, isto é, não fica subordinada à condição de realizar-se efetivamente, ou não, o casamento.

\section{Defeito que impeça o exercício de ofício ou profissão}

A quarta e última eventualidade é a do defeito que impeça o ofendido de exercer o seu ofício ou profissão, ou lhe diminua o valor do trabalho: além das despesas do tratamento e lucros cessantes até o fim da convalescença, pensão correspondente à importância do trabalho, para que se inabilitou, ou da depreciação, que ele sofreu (art. 1.539).

Tanto no caso de defeito em virtude do qual se veja o ofendido impossibilitado de exercer o seu ofício ou profissão, como no de que venha a sofrer no valor do seu trabalho, além da indenização prevista no aludido $\S 10^{\circ}$, e além das despesas do tratamento e lucros cessantes, até o fim da convalescença, manda o art. 1.539, seja incluída uma pensão correspondente à importância do trabalho para que se inabilitou o ofendido, ou da depreciação que ele sofreu.

Complementa o art. 1.538 que a indenização, no caso de ferimento ou outra ofensa à saúde, compreenderá, além das despesas de tratamento e dos lucros cessantes, "a importância da multa no grau médio da pena criminal correspondente"

Mas nem o Código Penal de 1890, nem o de 1940, previram pena pecuniária de multa para os crimes de ofensas físicas.

Sustentava Clovis BeVILÁQUA, em comentário ao dispositivo, que não se trata de pena ou elemento de pena criminal, pois que as lesões corporais não são punidas pecuniariamente: 
é uma pena civil, calculada pelo que o ofensor poderia ganhar por seus bens, emprego, indústria ou trabalho, durante o tempo da privação da liberdade, que lhe é imposta pela lei penal, no grau médio.

A opinião, e a dos poucos que a seguem, permaneceu porém isolada.

Tanto a doutrina como a jurisprudência consideram de aplicação impossível o art. 1538, nessa parte. Se a lei penal não prevê, para o caso, pena alguma de multa, como calcular a importância correspondente?

Não falta quem, na ausência de multa, conclua não existir, no caso, cominação alguma.

Mas, mesmo numa interpretação excessivamente limitada, há que reconhecer que tanto na hipótese do aleijão, como na de deformidade ( $\S 10^{\circ}$ do art. 1538), deve-se abstrair das expressões "esta soma", para calcular em dobro o valor da indenização das despesas de tratamento e dos lucros cessantes, sem prejuízo do disposto no $\S 2 .^{\circ}$. A soma será a das previstas no caput do art. 1538.

\section{Crime justificável}

Ainda que a morte, ou lesão, resulte de ato considerado crime justificável, manda o art. $1540 \mathrm{CC}$ que se apliquem as disposições precedentes.

Ao princípio, só abre exceção para o caso do ato ter sido perpetrado pelo ofensor em repressão de agressão do ofendido.

A morte, ou lesão corporal, mesmo em legítima defesa, ou em estado de necessidade, não dispensam, portanto, reparar o dano, caso não tenha sido o ofendido o agressor, ou o criador do estado de necessidade.

A hipótese prevista é a do dano sofrido por terceiro, estranho à injusta agressão, que deu causa à repulsa.

Se a vítima, ao repelir a agressão, fere, ou mata terceiro, terão este ou seus sucessores de ser indenizados do dano sofrido, embora disponha aquela de uma ação de regresso contra quem foi causador do evento.

É o que acontece com o crime praticado em estado de necessidade: a remoção de perigo iminente não autoriza dano às pessoas. Se daí resultar uma lesão pessoal a terceiro, este terá que ser indenizado pelo agente daquele ato, com a ressalva 
de que tenha sido ele mesmo o causador do perigo que se procurou afastar.

Mesmo Códigos mais modernos, como o italiano, não oferecem critérios mais satisfatórios, limitando-se, no art. 2057, a atribuir ao juiz a liquidação dos danos permanentes, levando em conta as condições das partes e a natureza do dano, sob forma de uma renda vitalícia, a ser constituída, nos termos do art. 1872, mediante alienação de um bem móvel ou imóvel, ou mediante cessão de capital.

Nosso CPC anterior determinava no art. 911 a conversão dos lucros cessantes em prestação de renda ou pensão, mediante pagamento de capital que aos juros legais assegurasse prestações devidas, e no 912 que fosse fixada, sempre que possível, na ação principal, compreendendo: custas judiciais, honorários de advogado, pensões vencidas e respectivos juros, devendo a sentença determinar a aplicação do capital em títulos da dívida pública federal para constituição de renda. Acrescentava:

"Este capital será inalienável durante a vida da vítima, revertendo após o falecimento desta no patrimônio do obrigado. Se a vítima falecer em conseqüência do ato ilícito, prestará o responsável alimentos às pessoas a quem ela os devia, levada em conta a duração provável da vida da vítima. Neste caso, a reversão do capital ao patrimônio do obrigado somente se efetuará depois de cessada a obrigação de prestar alimentos".

O critério, válido em 1940 , já não satisfaz por não se poder admitir que o capital permaneça ocioso durante dezenas de anos.

Um passo, no sentido de melhorá-lo, deu o atual CPC, art. 602 ao prever, no $\S 1 .^{\circ}$ que possa ser constituído por imóveis, ou por títulos da dívida pública.

Mas uma tomada de posição a favor da vítima não quer dizer que não se admitam atenuações que, sem prejudicá-la, venham beneficiar também o réu, no sentido de conceder-lhes facilidades razoáveis.

Assim, considerando que a lei não exige a imobilização daquele capital senão como garantia das prestações periódicas, de valor bem menor, e, pois, mais fácil, é admissível que a renda mensal seja paga no domicílio do beneficiário, de preferência por intermédio de agência bancária, e, se o responsável for empresa, conste de folha própria, asseguradas, em qualquer 
hipótese, a correção monetária automática na forma adotada para os créditos fiscais federais e a extensão à mesma renda das garantias e privilégios atribuídos ao salário.

É razoável ainda fique dispensado de qualquer outra garantia o devedor que for pessoa jurídica de direito público interno, autarquia, empresa pública, concessionária de serviço público, sociedade de economia mista e, a critério do Juiz, a empresa privada que comprovar plena solvabilidade e solidez.

\section{Responsabilidade civil dos que participaram de produtos de um crime}

Na conformidade do art. 1518 do Código Civil, responderão direta e solidariamente pela violação do direito de outrem, com os autores, os cúmplices e todas as pessoas indicadas no art. 1521, que encerra a lista com os que gratuitamente houverem participado nos produtos do crime, até à concorrente quantia.

Comenta Clóvis Beviláqua que a idéia da participação gratuita exclui a de co-delinqüência. Mesmo que a pessoa não tenha participado do delito, desde que tenha recebido graciosamente o seu produto, ou parte dele, deve restituí-lo, não obstante a sua inocência, indenizando, se tal não for possível, o dano, na parte correspondente ao seu locupletamento.

Estamos em pleno campo não de responsabilidade pelo ilícito, mas de ação in rem verso, fundada no enriquecimento sem causa.

Caso haja pluralidade de agentes diretos no ato ilícito, obriga a todos, solidariamente, o art. 1518, e se um deles ressarcir sozinho a totalidade do prejuízo, terá ação regressiva contra os demais.

$\mathrm{O}$ art. 1521 do Código Civil traça um rol, em seus primeiros quatro itens, das pessoas que têm o dever de vigilância sobre outras, presumindo sua culpa no dever de fiscalização quando haja necessidade da reparação do dano.

Trata-se, pois, de responsabilidade indireta, que não exclui a eventual responsabilidade direta do autor do ato ilícito, contra o qual é justo que se assegure ação regressiva, como autoriza o art. 1524, abrindo apenas exceção para o caso do descendente.

$\mathrm{E}$ quando forem múltiplos os agentes do ato ilícito? 
Aplicar-se-á então o princípio do art. 1518 do Código Civil, segunda parte, que responsabiliza a todos solidariamente pela reparação.

A ação regressiva não será admitida se tiver sido o responsável indireto quem determinou a prática do ato lesivo do agente direto: não há sequer, no caso, de considerar ter ocorrido falta de vigilância.

Com mais razão na exceção a que alude o art. 1524 citado: se o autor material do dano for descendente do responsável indireto. E caso típico de falta de dever de vigilância.

No caso de alienado ou de menor, a inimputabilidade do agente material exclui, com a sua culpa, a sua responsabilidade: a culpa é in vigilando do pai, tutor ou curador.

\section{9. necessário disciplinar o egoísmo humano}

Caracterizado o delito, constitui imperativo fundamental receba quem o praticou corretivo exemplar, não apenas no âmbito penal, como também no civil, que o desanime a persistir no seu dolo ou na sua leviandade, e que sirva de advertência a todos os demais.

Tudo quanto era possível dizer a respeito foi sintetizado de maneira profunda por IHERING: o direito deve procurar disciplinar o egoísmo humano.

Para tanto são indispensáveis três ordens de contribuições.

Em primeiro lugar, uma completa reforma da legislação civil, que deixe de paliativos, que servem apenas para incentivar os criminosos e os irresponsáveis, e que enfrente decididamente o problema da quase total impunidade, sacudindo pelas bases toda a estrutura anquilosada que nos rege.

Quantos milhares de pessoas não continuam perdendo a vida em acidentes automobilísticos? Quantas não ficam estropiadas pelo resto da vida?

Por que? Acima de tudo, porque as medidas repressivas, nesse setor, não têm, entre nós, qualquer eficácia.

Em contraste, na França, o motorista que ultrapasse faixa de segurança do pedestre fica sujeito a uma multa correspondente a $\operatorname{Cr} \$ 1.700,00$, e na reincidência, tem a carta apreendida até 12 meses.

No Japão, o responsável por uma morte no trânsito pode ser condenado a pagar indenização de até um milhão de dólares 
e não é raro o culpado ter de vender seus bens para honrar a dívida com a família do morto.

Já se registraram casos de motoristas que praticaram o haraquiri, por ter sido sua vida econômica irremediavelmente destruída por causa de um acidente de trânsito.

$\mathrm{Na}$ Alemanha, as autoridades garantem que o respeito às normas de trânsito deve-se principalmente ao medo do famoso "Arquivo de Flensburg", da cidade do mesmo nome, um prontuário completo para cada um dos portadores de habilitação para dirigir, que consigna todas as faltas graves cometidas pelos motoristas.

Falhas correspondentes a doze pontos, no espaço de dois anos, suspendem automaticamente a habilitação por um prazo de seis meses. Na reincidência, a punição é por dois anos e, na terceira vez, a perda da habilitação é definitiva.

Os bons propósitos revelados pelo CC argentino, art. 1078, mandando pagar no caso de "delito do direito criminal", não somente perdas e danos, mas também o agravo moral, a moléstia na segurança pessoal ou no gozo dos bens da vítima, ou ferindo suas legítimas afeições, ficam, na prática, bastante reduzidos se comparados com o mal ocasionado pela perda de uma vida, limitando-se, analogamente ao que faz o art. $1537 \mathrm{CC}$ pátrio, e, sem que a providência fosse melhorada no 984 do Projeto de 1975, ao pagamento de todas as despesas com a assistência do falecido e com o seu funeral, além do que for necessário à subsistência da viúva e filhos do morto, confiando ainda à prudência dos juízes fixar o montante da indenização e o modo de satisfazê-la (1084).

Nem um estremecimento por parte do legislador diante dessa perda irreparável de um chefe de família, nem comiseração pela viúva e pelos órfãos, nem um pouco de vibração humana.

Não resta dúvida que é ao direito penal que cabe punir o delito, dando uma satisfação à sociedade.

o crime contra a vida, para citar apenas o mais expressivo, tem reflexos de ordem patrimonial e de ordem moral que jamais serão satisfatoriamente cicatrizados. Mas, admiti-lo, não significa dispensar o causador do abalo de dar uma satisfação menos inadequada.

Não é plausível que a repressão exercida no recinto criminal não encontre no civil uma correspondência mais consentânea com o espírito de uma indenização menos odiosa. 
E chegado o momento de estabelecermos também no âmbițo pecuniário uma diferenciação no tratamento entre aquele que mata, mutila, humilha deliberadamente ou culposamente, e aquele que o faz sem essa intenção.

Isso é indispensável até por uma questão de coerência, pois não se justifica que se repare o mal causado a uma mulher agravada em sua honra por crime sexual e não se cuide de restaurar adequadamente o prejuízo ocasionado pela morte de um pai, de um esposo ou de um filho exemplar.

Não surpreende que, diante de um texto dessa natureza, a jurisprudência denegue praticamente indenização em caso de morte mesmo dolosa, com receio, talvez, de arbitramentos exagerados.

Bem por isso, entre muitos outros, encarecia o saudoso EDUARDo Espínola que fora de se desejar que o CC "encerrasse disposições claras e precisas sobre este assunto de ressarcimento do dano em geral, sendo para notar que os princípios estabelecidos pelo projeto BEVILÁQUA, com referência especial às obrigações decorrentes de atos ilícitos, não satisfazem absolutamente" (Direito Civil Brasileiro, vol. 2., pág. 207).

Também J. M. DE CaRvalho Santos, $C C$ Brasileiro Interpretado, Rio de Janeiro, Freitas Bastos, 3. ${ }^{a}$ ed., 1946, vol. XXI, pág. 69, critica a orientação do legislador na redação do art. 1537 por ter restringido em demasia o limite da indenização do dano que possa resultar do ato ilícito.

Transcreve acórdão do Tribunal de Justiça de São Paulo, e o voto divergente de ANTONINO VIEIRA, ressaltando que nos casos de ferimento ou de que resulte defeitos, os arts. 1.538 e 1.539 mandam indenizar o ofendido das despesas de tratamento e dos lucros cessantes, além de uma multa no primeiro caso e de uma pensão no segundo.

"Ora, seria um contra-senso inconcebível que no caso de morte imediata, com desaparecimento do cadáver, por ter sido queimado, por exemplo, ou atirado à água corrente, a indenização se limitasse às despesas de luto, ou nenhuma fosse paga, se a família dispensasse."

Demonstra que "a indenização deve ser sempre a mais completa que for possível, e a pena civil ou criminal deve ser proporcionada ao ato ilícito e suas conseqüências" e passa a socorrer-se, uma vez que o CC brasileiro não contém nem preceito genérico, como o do art. 1.078 do argentino, para 
todos os delitos, nem específico, de subsídios doutrinários para propugnar o reconhecimento de um direito à indenização pelo dano moral.

Em "Comentário" a esse voto, J. M. DE Azevedo MARQUEs, na mesma revista, págs. 546-549, faz ver que a vida moderna nem sempre suporta o classicismo hierático: exige maior elasticidade de hermenêutica.

"A aplicação nua e crua das palavras legislativas pode ser mui honesta, pode ser a resultante de uma "economie de pensée", no dizer de um escritor, mas não será, muita vez, justa e, portanto, não será jurídica, eis que o Direito deve ser a justiça social, que se impõe ao bom senso da humanidade."

Considera desnecessário recorrer ao conceito do dano moral, questão diferente e autônoma, propugnando antes, para a solução do problema, uma ampliação da vaga alusão do CC ao "luto de família":

“Tomada à letra essa expressão, provocará absurdos e desigualdades injustas, eximindo muitas vezes o devedor de satisfazer qualquer indenização. "Luto", na linguagem popular mais corrente, se limita às "vestimentas lúgubres", quando são usadas. Mas, no meu sentir, não deve ser essa a verdadeira e única significação, quando a lei manda indenizar o luto da família. Este é mais amplo; é também, no dizer dos lexicons: "o profundo sentimento de tristeza causado pela perda de pessoa cara"; ou genericamente, "a tristeza causada por desgostos e sofrimentos". Pode haver luto sem haver morte; pode alguém estar de luto sem vestir roupas especiais. O luto não é somente o sinal de dor; é o sofrimento moral íntimo; d'onde surge para logo, necessariamente, logicamente, a idéia de dano ou melhor, de dor moral, esteja ou não escrito nas leis."

Temos aí a pedra angular de todo o edifício da responsabilidade civil: não há um ato ilícito mais grave do que esse, e a severidade com que seja cominada no direito civil aquela pena que não é poupada no direito criminal, estabelecerá a proporcionalidade com a indenização a ser imposta a todos os demais atos lesivos, sejam eles dolosos ou meramente culposos. 
O que tem sido feito para melhorar essa situação?

Pouco, muito pouco.

O Projeto de Código Civil de 1975, depois de repetir, no art. 184, o art. 159, ampliando o conceito de ato ilícito para incluir o dano mesmo simplesmente moral, reproduz, com poucas inovações, nos arts. 963-990, mesmo na sua estrutura arcaica, o disposto nos arts. 1.519 a 1.551, com supressão de vários dispositivos.

Até a linguagem do começo do século é perpetuada ("patrão, amo ou comitente"!), limitando-se, praticamente, a dar maior realce à teoria do risco e à do dano objetivo.

A contribuição mais importante é a do parágrafo único do art. 963, mandando reparar o dano, independentemente de culpa "quando a atividade normalmente desenvolvida pelo autor do dano implicar, por sua natureza, grande risco para os direitos de outrem, salvo se comprovado o emprego de medidas preventivas tecnicamente adequadas"

Mas a preocupação mais com o autor do dano do que com a infeliz vítima continua, e transparece no

"Art. 980 - A indenização mede-se pela extensão do dano.

Parágrafo único - Se houver excessiva desproporção entre a gravidade da culpa e o dano, poderá o juiz reduzir, equitativamente, a indenização."

Por estranho que pareça, melhor contribuição encontra-se no anteprojeto do Código de Processo Penal, que se ocupa especificamente com a reparação do dano causado pelo crime (arts. 786-820).

A indenizaçã̃o deve ser paga em execução à própria sentença penal, extraindo o interessado, neste juízo, carta de sentença.

Dará, assim, início à execução apresentando requerimento no qual formula os quesitos para o arbitramento do dano. Se o juiz penal tiver, também, competência civil, a execução correrá nos próprios autos da ação penal, dispensada a carta de sentença.

Mas a solução para o eterno problema da falta de recursos da maioria dos agentes dos atos lesivos talvez possa ser encontrada num mais completo aproveitamento da idéia do seguro 
obrigatório de danos pessoais, instituído pelo Decreto-lei n. 73, de 27-11-1966, cobrindo a responsabilidade civil por morte, invalidez permanente e despesas médicas e suplementares da vítima de acidente de tráfego causado por veículo automotor ou por sua carga (art. 20, b e a1.1), independentemente da culpa do condutor do veículo que causou o dano (Lei n. 6.194/ 74 , art. $5 .{ }^{\circ}$ ).

Naturalmente, terão que ser tomadas providências para aproximar à realidade a indenização por morte que é de apenas 40 salários mínimos; por invalidez permanente, de até 40 salários; pelas despesas médicas e suplementares comprovadas, de até 8 salários, como reembolso à vítima (Lei n. 6.194/74, $\left.\operatorname{art} .3^{\circ}\right)$.

De qualquer maneira, trata-se de uma obrigação independente da prevista no CC, arts. 1.538 e 1.539, tendo pois direito a vítima de exigir a cumulação de ambas as indenizações.

Só depois disso é que se poderá esperar uma atuação mais enérgica por parte dos nossos tribunais (segunda das mencionadas contribuições), "avec l'aide de juges dévoués et consciencieux", como acentua AleXANDRe MARTIN ACHARD:

"A tarefa do juiz nunca é fácil, mas no domínio da reparação do dano moral, mais do que em qualquer outra, temos o direito de contar com juízes perspicazes, em condições de apreciar as gradações mais delicadas dos sentimentos hümanos e desdobrados de moralistas de vistas elevadas.

Numa instituição que diz respeito às questões mais graves, uma vez que os juízes têm em mãos o que os homens têm de mais sagrado, seu patrimônio moral, o dever do juiz está cheio de escolhos, e incumbe àquele que é convocado a conhecer semelhantes questṍes, um estudo aprofundado dos casos que ele julga, um amor intenso da justiça e da verdade."

A tudo sobreleva ainda uma condição primordial: uma ampla campanha de conscientização, de chamamento à responsabilidade sobre os males decorrente desse completo abandono, a que, com tanto descuido é relegado esse o bem inestimável que é a integridade física, a própria vida. tados!

Que contraste com o que ocorre com os países mais adian- 
Takashi Kicuchi, diretor da Yakult em Londrina, por causa de uma bola de golfe abateu com um tiro o menor de 9 anos, Vanderlei, no dia 7-1-1973.

Consternado com a notícia, Hisami Matzuzomo, presidente da empresa, partiu imediatamente do Japão, por via aérea e apresentou-se ao operário Adão Rodrigues, pai da vítima, em seu próprio humilde lar, trazendo-lhe presentes e pedindo que os aceitasse, em obediência a um costume de seu país natal, com as seguintes expressões:

"O presente é meu. Não tem nenhuma vinculação com o assassino e se sua família aceitá-lo, significaria o perdão para mim."

A reação de Maria, mãe de Vanderlei na sua simplicidade, é bem expressiva do sentimento de todas as vítimas, em situações análogas:

- "Perdoar o assassino? nunca"

- "Não venho em nome de quem matou seu filho. Peço perdão para mim. Quero voltar à minha terra sabendo que os senhores me perdoaram"

- "Eu perdôo a mulher do japonês que matou meu filho. O senhor não tem nada com isso, não tem culpa de nada. Eu perdôo o senhor, mas aquele tem de morrer na cadeia, para não fazer mais o que fez. Se ele ficar solto pode fazer o mesmo com outra criança"

Pedindo desculpas em nome da Yakult, e manifestando o seu repúdio por esse ato a todo o povo londrinense, Hisami estendeu dois envelopes ao pai da vítima, esclarecendo:

"Em cada um deles há 10 mil cruzeiros para o senhor. É um presente meu".

O intérprete acrescenta que este é um costume japonês. Adão Rodrigues assinou um documento, ganhou mais um televisor em cores e a promessa de receber mais dinheiro.

Mais comovente ainda foi a informação de que esse sentimento de solidariedade não era a manifestação de uma pessoa isolada, embora Presidente da organização, que acrescentou:

"No Japão, os funcionários da minha empresa estão fazendo uma coleta. São 70 mil empregados e eu vou enviar o dinheiro ao prefeito de Londrina, para que ele entregue ao senhor, está bem?" 


\section{Bibliografia}

Aragão, R. D. Moniz de - Da Reparação do Dano Causado pelo Crime, Rev. dos Tribunais, vol. 424, 1971, páginas 11-20.

Azevedo, Vicente de - Crime. Dano. Reparação, São Paulo, Ed. Revista dos Tribunais, 1934.

Pimentel, Manoel Pedro - Delito e Reparação do Dano no Anteprojeto do CC Brasileiro, Rev. dos Tribunais, vol. 446, 1972, págs. 11-21. 